\title{
Prevalence of Stunting and Associated Factors among Children Aged 06-59 Months In Southwest Ethiopia: A Cross-Sectional Study
}

\author{
Melkamu Beyene Teferi*, Hamid Yimam Hassen, Amanu Kebede, Emebet Adugnaw, Gebrelibanos \\ Gebrekrstos, Mebrahtom Guesh \\ Mizan-Tepi University, College Of Health Sciences, Department Of Public Health, Mizan Teferi, Ethiopia
}

Received: October 10, 2016; Accepted: November 15, 2016; Published: December 15, 2016

*Corresponding author: Mr. Melkamu Beyene Teferi, Mizan Tepi University, college of Health Sciences, Department Of Public Health.

Tel: +251-910-586-634; Fax: 04733603 44; E-mail: melkieb12@gmail.com

\begin{abstract}
Introduction: Nutritional Stunting, which is height for age below that expected on the basis of International growth reference, is a very serious type of malnutrition in that it develops slowly through time before it is evident. Stunting is one of the most important public health problems in Ethiopia. The objective of this study is to assess the prevalence of stunting and associated factors among fewer than five children in southwest Ethiopia.
\end{abstract}

Methods: A community based cross-sectional study was conducted by simple random sampling technique with sample size of 356 among 06-59months children. Interviewer administered structured questionnaires and anthropometric measurement was used to collect data. The data was entered using SPSS version 20 and analysis was done by SPSS version 20. Bivariate and multivariate logistic regression analysis was used. The variables which had significant association were identified on the bases of $\mathrm{P}$ value $\leq 0.05$ and $95 \% \mathrm{CI}$

Result: A total of 324 children's were participated in the study with a response rate of $91 \%$. In the study, $33.3 \%$ of $06-59$ months children were stunted in shey bench district. Children aged 12-24months were about 0.06 times [AOR0.06; 95CI (0.02-0.08)] and children above 24 months were 0.12 times [AOR0.12; $95 \%$ CI (0.03-0.56)] less likely to be affected by stunting respectively. Children who had born less than 2 years interval were 2.31 times more likely to be affected by chronic malnutrition [AOR 2.31;95 \% CI (1.43- 3.08) ]. Children who had started complementary feeding at less than six months or above six months were 3.78 [AOR 3.78; $95 \%$ CI (1.39-4.25)] times more likely to be affected by stunting than those started complementary feeding at the age of 6 months.

Conclusion and recommendation: The result of this study described that the prevalence of stunting among children age 0659 months was relatively high (33.3\%). Children age, age at which complementary feeding started and birth interval were found to be associated factors of stunting. Promoting appropriate maternal feeding at pregnancy including optimal breast feeding, timely starting of complementary feeding and exceeding of birth interval more than 24 months is essential to prevent stunting (chronic malnutrition) among under five children.

Keywords: Stunting; Under Five Children; Factors; Shey Bench District; Ethiopia;

\section{Background}

The term malnutrition generally refers both to under nutrition and over nutrition, but in this situation we use the term to refer solely to a deficiency of nutrition. Many factors can cause malnutrition, most of which relate to poor diet or severe and repeated infections, particularly in underprivileged populations. Inadequate diet and disease, in turn, are closely linked to the general standard of living, the environmental conditions, and whether a population is able to meet its basic needs such as food, housing and health care $[1,2]$.

Malnutrition among the under-5 years is a leading factor underlying child mortality in Sub-Saharan Africa, and contributes to 2.2 million deaths and the overall status of health and health care practices of all disability adjusted-life-years lost worldwide for children under five years old [2, 3].

Malnutrition continues to be a major public health problem in developing countries. It is the most important risk factor for the burden of many diseases [4-6]. In Ethiopia, child malnutrition rate is one of the most serious public health problem and the highest in the world. High malnutrition rates in the country pose a significant obstacle to achieving better child health outcomes [7-9].

Nutritional Stunting, which is height for age below that expected on the basis of International growth reference, is a very serious type of malnutrition in that it develops slowly through time before it is evident. The high prevalence of stunting among the children reflects inadequate health services, poor water and sanitation, poor maternal and child care practices and insufficient access to food .This is caused by poor health service delivery at village level and subsequent health system levels. Nutritional status is the result of complex interactions between food consumption and the overall status of health and health care practices $[10,11]$. 
Numerous socioeconomic and cultural factors influence patterns of feeding children and nutritional status of women and children. The period from birth to age two is especially important for optimal growth, health, and development. Unfortunately, this period is often marked by micronutrient deficiencies that interfere with optimal health, growth and development $[12,13]$.

Improving overall nutritional status throughout the life cycle is crucial to maternal and child health. Women who become malnourished during pregnancy and children who fail to grow and develop normally due to malnutrition at any time during their life, including during fetal development, are at increased risk of prenatal problems, increased susceptibility to infections, slowed recovery from illness, and possibly death. Improving maternal nutrition is crucial for improving children's health. The poor nutritional status of children and women has been a serious problem in Ethiopia for many years [14].

Even though Child malnutrition remains one of the most important concerns of the world including Ethiopian government only few studies done at national and regional levels, the prevalence and risk factors at sub-regional or community level have been insufficiently emphasized, which makes interventions difficult in such circumstances .For example, according to the 2011 DHS, the prevalence of stunted, wasted and underweight children in the region (SNNPR) was $44.1 \%, 7.6 \%$ and $28.3 \%$, respectively, indicating that there are several zones and districts with higher prevalence rates than the regional average [9].

Having this in mind, the aim of our study was to determine the magnitude of chronic malnutrition and identify the major factors associated with it that will guide a good intervention approach to halt the problem.

\section{Methodology}

\section{Study Design, area and period}

A community based cross-sectional study was conducted to assess the prevalence of stunting among under five children. The study was conducted at shey Bench district from April 1 to May 30, 2016. shey bench is located about 593 Kilo meter from Addis Ababa (capital city of Ethiopia) in southwest direction. Based on central statistical agency in 2010 this town has an estimated total population of 27, 975 of which 13002 men, 14973 women and 4210 under five children.

\section{Source Population and sampling}

The Source population was children (06-59 months) of age who lived with their mother's or caregivers in the house holds of Shay Bench district. The Study populations were children 0659 months of age who lived with their mothers or care givers in the sampled kebeles of Shay Bench district. All children among age of 06-59 months in Shay Bench town were included and Children who are critically sick and that makes difficult to take anthropometric measurement were excluded. For sample size calculation we use single population proportion formula considering the following assumptions: 95\% confidence level, proportion (p) of stunting 35\% studied in Benchi Maji zone and $5 \%$ margin of error (d). $\mathrm{ni}=(1.96)^{2}(0.35)(0.65) /(0.05)^{2}=350$. Since the source population is 4210 which is less than 10,000 we need to adjust the sample size. Final $(\mathrm{n})=\mathrm{ni} / 1+\mathrm{ni} / \mathrm{N}$, Where $\mathrm{N}$ is the source population. $\mathrm{n}=350 / 1+350 / 4210=324$. By adding $10 \%$ non respondent rate the final required sample size was 356 . Lists of children aged between 06 and 59 months along with their mothers residing in all kebeles (the smallest administrative unit) of shey bench district were taken from health extension workers and then sampling frame was constructed for each kebeles. Simple random sampling technique was used to select a sample of 356 children proportionally from all kebeles by using lottery method.

\section{Data Collection Procedure and Tools}

For a Socio economic and demographic, Dietary, Environmental and Health care characteristics data was collected face to face interviewing mothers/care takers by using a structured questionnaire which is adopted from other similar studies. Anthropometric Measurements was collected using the procedure stipulated by the WHO (1995) for taking Anthropometric measurements. Adherence to this procedure was ensured. The protocol used was as follow.

Length: - Length measurement for children less than 24 months was made by laying flat on the length board. The sliding piece was placed at the edge of the bare feet and at the head (with crushing of the hair) touched the other end of the measuring device.

Height: - Height was taken in a standing position for children greater than 24 months .The measurement was taken to the nearest $0.1 \mathrm{~cm}$ using short height measuring board.

\section{Operational Definition}

Stunting was defined as $\mathrm{HAZ}<$ minus two Z-score based on WHO reference group.

\section{Data Quality Assurance, Processing and Analysis}

Before the actual data entry was started completeness, accuracy, and consistency of the collected data were checked on daily basis during data collection by the principal investigators. Data were entered, cleaned and analyzed by using SPSS version 20.0 statistical software. Descriptive statistics were done and presented by using tables and figures. Bivariate logistic regression analysis was used to assess the association between each independent variable with the dependent variables. Those variables that have been associated with the dependent variables at $\mathrm{p}$-value of less than 0.2 were fitted in to multivariate logistic regression models to control the effects of confounding. Those variables having $\mathrm{p}$ - value of less than 0.05 was considered as significant.

\section{Results}

\section{Characteristics of the sample}

A total of 324 children aged 06 to 59 months along with their mothers/care givers were enrolled in the study, with a response rate of $91 \%$. For all parental and children socio-demographic 
characteristics see Table 1. Among the children, 126(38.9\%) were found in the age group of between 12-24 months. The mean age was $27.77 \pm 14.78$ SD months. 164(50.6\%) were female.

\section{Environmental, Health care and children feeding Characteristics of children and parents}

From the total households $150(46.3 \%)$ of them had water

Table 1: Socio-demographic and economic characteristics of parents and children among 06-59 months age in Shay Bench district, southwest Ethiopia, $2016(\mathrm{n}=324)$.

\begin{tabular}{|c|c|c|}
\hline Characteristics & Frequency (n) & Percentage (\%) \\
\hline Sex of the child & $\begin{array}{l}160 \\
164\end{array}$ & $\begin{array}{l}49.4 \\
50.6\end{array}$ \\
\hline $\begin{array}{c}\text { Children age in month } \\
6-11 \\
12-24 \\
>24\end{array}$ & $\begin{array}{c}86 \\
126 \\
112\end{array}$ & $\begin{array}{l}26.5 \\
38.9 \\
34.6\end{array}$ \\
\hline $\begin{array}{c}\text { Mothers age at pregnancy } \\
\qquad 20 \\
20-35 \\
>35\end{array}$ & $\begin{array}{c}86 \\
219 \\
19\end{array}$ & $\begin{array}{c}26.5 \\
67.6 \\
5.9\end{array}$ \\
\hline $\begin{array}{c}\text { Marital status of the mother } \\
\text { Married } \\
\text { divorced } \\
\text { Widowed } \\
\text { Single }\end{array}$ & $\begin{array}{c}260 \\
32 \\
17 \\
15\end{array}$ & $\begin{array}{c}80.2 \\
9.9 \\
5.2 \\
4.6\end{array}$ \\
\hline $\begin{array}{l}\text { Bench } \\
\text { Kefa } \\
\text { Amhara } \\
\text { Oromo } \\
\text { Gurage } \\
\text { Others }\end{array}$ & $\begin{array}{l}110 \\
77 \\
67 \\
42 \\
18 \\
10\end{array}$ & $\begin{array}{c}34 \\
23.8 \\
20.7 \\
13 \\
5.6 \\
3.1\end{array}$ \\
\hline $\begin{array}{l}\text { Protestant } \\
\text { Orthodox } \\
\text { muslim } \\
\text { Others }\end{array}$ & $\begin{array}{c}96 \\
181 \\
45 \\
2\end{array}$ & $\begin{array}{c}29.6 \\
55.9 \\
13.9 \\
0.6\end{array}$ \\
\hline $\begin{array}{c}\text { Educational status of a mother } \\
\text { No education } \\
\text { Primarily } \\
\text { Secondary } \\
\text { Higher institution }\end{array}$ & $\begin{array}{c}102 \\
152 \\
37 \\
33\end{array}$ & $\begin{array}{l}31.5 \\
46.9 \\
11.4 \\
10.2\end{array}$ \\
\hline $\begin{array}{c}\text { Education status of a father } \\
\text { No education } \\
\text { Primarily } \\
\text { Secondary } \\
\text { Higher institution }\end{array}$ & $\begin{array}{c}54 \\
118 \\
70 \\
46\end{array}$ & $\begin{array}{l}18.5 \\
41.5 \\
23.8 \\
16.2\end{array}$ \\
\hline $\begin{array}{c}\text { Occupational status of a mother } \\
\text { House wife } \\
\text { Government employee } \\
\text { Non government employee } \\
\text { merchant } \\
\text { Self employee } \\
\text { Others }\end{array}$ & $\begin{array}{c}195 \\
28 \\
9 \\
44 \\
40 \\
8\end{array}$ & $\begin{array}{c}60.2 \\
8.6 \\
2.8 \\
13.8 \\
12.3 \\
2.5\end{array}$ \\
\hline $\begin{array}{r}\text { Family monthly income } \\
<1500 \\
>=1500\end{array}$ & $\begin{array}{c}229 \\
95\end{array}$ & $\begin{array}{l}70.7 \\
29.3\end{array}$ \\
\hline
\end{tabular}

source from public pipe, 306(94.4\%) households have Functional toilet. Of the total children mothers 157(48.5\%) had ANC visit of 2-3 times during their pregnancy, 265 (81.8\%) give birth at health institutions and $100(30.9 \%)$ of the mothers had no post natal care visit. From the total study participants 192(59.9\%) of children had birth weight of 2.5-4 kilogram and 123 (38\%) of children were in the second and third birth order. Among study participants 263(81.2\%) of children were fully immunized and $69(21.3 \%)$ had fever, $81(25 \%)$ had diarrhea in the past two weeks.

Among 324 children 321(99.1\%) were breast fed, 312(96.3\%) initiated to breast feed within one hour of delivery and 84 (25.9 $\%)$ of children had started complementary feeding at age of 6 months. For all environmental, health care and child feeding characteristics see table 2 below.

\section{Prevalence of stunting among 06-59 months children}

Based on WHO criteria the prevalence of stunting among children of 6-59 months in shey bench district is 33.3\%.

\section{Factors associated with stunting among 6-59 months children}

Multivariate logistic regression analysis revealed that age of the child, preceding birth interval and age at which complementary feeding started were associated with stunting at $\mathrm{p}$ value $<0.05$. Children aged $12-24$ months were about 0.06 times less likely to be affected by stunting [AOR0.06; 95CI (0.02-0.08)] and children above 24 months were 0.12 times less likely to be affected by stunting [AOR0.12; $95 \% \mathrm{CI}(0.03-0.56)]$ compared to children aged 6-11 months.

Children who had born less than 2 years interval were 2.31 times more likely to be affected by chronic malnutrition [AOR 2.31; $95 \%$ CI (1.43- 5.08) ] as compared with children who had born more than 2 years interval.

Children who had started complementary feeding at less than six months or above six months were 3.78 [AOR 3.78; 95 \%CI (1.39-5.25)] times more likely to be affected by stunting than those started complementary feeding at the age of 6 months.

\section{Discussion}

Nutritional Stunting, which is height for age below that expected on the basis of International growth reference, is a very serious type of malnutrition in that it develops slowly through time before it is evident.

This study intended to assess the prevalence of stunting and associated factors among 6-59 months children in shey bench district. Based on this study the prevalence of stunting was $33.3 \%$; 95\%CI.This study was in line with the study conducted in Mizan Aman town, 34.5\%, in Hosanna (35.4\%) and Bangladesh (34.4\%) [15-17]. the prevalence is higher than the study conducted by Ethiopian Base line survey 2010, (25\%) [8] And the study conducted in Somali region (17.2\%) [18]. However, the prevalence of stunting in the study area was lower than the study conducted in north shoa (47.6\%), in Lalibela (47.3\%) and Vietnam (44.3\%) [19-21]. the prevalence of stunting in the study 
Table 2: Environmental, health care and child feeding characteristics of children among 5 to 59 months in Shay Bench district, southwest Ethiopia , $2016(n=324)$

\begin{tabular}{|c|c|c|c|}
\hline Characteristics & Category & $\begin{array}{l}\text { Frequency } \\
\text { (n) }\end{array}$ & $\begin{array}{l}\text { Percent } \\
(\%)\end{array}$ \\
\hline Main source of water & \begin{tabular}{|} 
Private pipe \\
Public pipe \\
Boon water \\
Protected well \\
Unprotected well
\end{tabular} & $\begin{array}{c}91 \\
150 \\
8 \\
63 \\
12\end{array}$ & $\begin{array}{c}28.1 \\
46.3 \\
2.5 \\
19.4 \\
3.7\end{array}$ \\
\hline Availability of toilet & $\begin{array}{l}\text { Yes } \\
\text { No }\end{array}$ & $\begin{array}{c}306 \\
18\end{array}$ & $\begin{array}{c}94.4 \\
5.6\end{array}$ \\
\hline $\begin{array}{l}\text { Frequency of ANC follow } \\
\text { up }\end{array}$ & $\begin{array}{c}\text { none } \\
1 \\
3-\mathrm{Feb} \\
>3\end{array}$ & $\begin{array}{c}17 \\
43 \\
157 \\
107\end{array}$ & $\begin{array}{c}5.2 \\
13.3 \\
48.5 \\
33\end{array}$ \\
\hline Place of delivery & $\begin{array}{c}\text { Health institution } \\
\text { home }\end{array}$ & $\begin{array}{c}265 \\
59\end{array}$ & $\begin{array}{l}81.8 \\
18.2\end{array}$ \\
\hline PNC & $\begin{array}{l}\text { Yes } \\
\text { No }\end{array}$ & $\begin{array}{l}224 \\
100\end{array}$ & $\begin{array}{l}69.1 \\
30.9\end{array}$ \\
\hline Birth weight of a child & $\begin{array}{c}<2.5 \mathrm{~kg} \\
2.5-4 \mathrm{~kg} \\
>=4 \mathrm{~kg}\end{array}$ & $\begin{array}{c}60 \\
194 \\
70 \\
\end{array}$ & $\begin{array}{l}18.5 \\
59.9 \\
21.6\end{array}$ \\
\hline Birth order of a child & $\begin{array}{l}1 \\
3-\mathrm{Feb} \\
5-\mathrm{Apr} \\
>5\end{array}$ & $\begin{array}{c}120 \\
123 \\
44 \\
37\end{array}$ & \begin{tabular}{c|}
37 \\
38 \\
13.6 \\
11.4
\end{tabular} \\
\hline Birth interval of a child & $\begin{array}{l}<2 \text { years } \\
>2 \text { years }\end{array}$ & $\begin{array}{l}216 \\
108\end{array}$ & $\begin{array}{l}66.7 \\
33.3\end{array}$ \\
\hline Ever breast feed child & $\begin{array}{l}\text { Yes } \\
\text { No }\end{array}$ & $\begin{array}{c}321 \\
3\end{array}$ & $\begin{array}{c}99.1 \\
0.9\end{array}$ \\
\hline initiation of breast feeding & $\begin{array}{l}\text { Within one hour } \\
\text { After one hour }\end{array}$ & $\begin{array}{c}312 \\
12\end{array}$ & $\begin{array}{c}96.3 \\
3.7\end{array}$ \\
\hline Child feed colostrums & $\begin{array}{l}\text { Yes } \\
\text { No }\end{array}$ & $\begin{array}{c}256 \\
65\end{array}$ & $\begin{array}{l}79.9 \\
20.1\end{array}$ \\
\hline Duration of breast feed & $\begin{array}{l}<12 \text { months } \\
12-24 \text { months } \\
>24 \text { months }\end{array}$ & $\begin{array}{c}44 \\
243 \\
37 \\
\end{array}$ & $\begin{array}{c}13.6 \\
75 \\
11.4\end{array}$ \\
\hline $\begin{array}{l}\text { complementary food } \\
\text { started }\end{array}$ & $\begin{array}{c}\text { At } 6 \text { months } \\
<6 \text { and }>6 \text { months }\end{array}$ & $\begin{array}{c}84 \\
240\end{array}$ & $\begin{array}{l}25.9 \\
74.1\end{array}$ \\
\hline Feeding material & $\begin{array}{l}\text { spoon } \\
\text { cup } \\
\text { hand } \\
\text { Bottle }\end{array}$ & $\begin{array}{c}123 \\
55 \\
47 \\
99\end{array}$ & $\begin{array}{c}38 \\
17 \\
14.5 \\
30.5\end{array}$ \\
\hline $\begin{array}{l}\text { History of pre lacteal } \\
\text { feeding }\end{array}$ & $\begin{array}{l}\text { Yes } \\
\text { No }\end{array}$ & $\begin{array}{c}49 \\
275\end{array}$ & $\begin{array}{l}15.1 \\
84.9\end{array}$ \\
\hline Immunization status & $\begin{array}{l}\text { Fully immunized } \\
\text { on immunization } \\
\text { Not immunized }\end{array}$ & $\begin{array}{c}263 \\
25 \\
36\end{array}$ & $\begin{array}{c}81.2 \\
7.7 \\
11.1\end{array}$ \\
\hline $\begin{array}{l}\text { Fever for the last two } \\
\text { weeks }\end{array}$ & $\begin{array}{l}\text { yes } \\
\text { No }\end{array}$ & $\begin{array}{c}69 \\
255\end{array}$ & $\begin{array}{l}21.3 \\
78.7\end{array}$ \\
\hline Diarrhea for the last weeks & $\begin{array}{l}\text { Yes } \\
\text { No }\end{array}$ & $\begin{array}{c}81 \\
243\end{array}$ & $\begin{array}{l}25 \\
75\end{array}$ \\
\hline Frequent diarrhea & $\begin{array}{l}\text { Yes } \\
\text { No }\end{array}$ & $\begin{array}{c}49 \\
275\end{array}$ & $\begin{array}{l}15.1 \\
84.9\end{array}$ \\
\hline
\end{tabular}

Note: All of the characteristics related to health care and feeding practice is concerning to index child. area was also lower than a research conducted in Bule hora, southern Ethiopia (47.6\%) [22].

The difference in prevalence might be due to this might be due to difference in method used, sample size variation and child feeding practice of the community.

According to this study, Childs age was one of the socio demographic factors associated with stunting in the study area. Children at the age of $6-11$ months were more likely to be stunted than those children in the age of 12-24 months and greater than 24 months.

This study was in agreement with the study conducted in Lalibela town [20], in Hosanna [16] and in Mizan Aman town [15] and not in agreement with the study conducted in Bule hora district,south Ethiopia [22].

This might be due to poor nutritional status of mother's at pregnancy, inappropriate infant and young child feeding practices including breast feeding and complementary feeding and other related factors which were needed to be undergone beginning from conception, through a mother's pregnancy and up until the age of one which was the most critical period in a child's development after child reaches above 24 months of age stunting was irreversible.

Another factor associated with stunting in the study area was age at which complementary feeding started. The result of this study revealed that children who had started complementary feeding at the age of below or above 6 months were more likely to be stunted than those who had started complementary feeding at the age of 6 months.

The association of this dietary factor with stunting was in line with the study done in Meskan district, Gurrage zone, southern Ethiopia [23].

This might be due to inappropriate timing for introducing some kinds of complementary food to a child may affect his/her nutritional status because his/her digestive and immune systems are not yet mature. Introducing supplements before earlier, especially under unhygienic conditions, could be predisposing factor for infection and it leads to malnutrition.

The other factor that was significantly associated with stunting was preceding birth interval of the child Children who had preceding birth interval of less than 24 months were more likely to be stunted than children with preceding birth interval of greater than or equal to 24 months. This result was in line with a study conducted in Mizan Aman town and harerge zone [15, 24]. This might be due to the child may not be breast feed up to 24 months and a mother may not be feed and give care appropriately due to her second early pregnancy.

\section{Conclusion}

The result of this study described that the prevalence of stunting among children age 6-59 months was relatively high 
Table 3: A bivariate and multivariate logistic regression output showing factors associated with stunting among 06 to 59 months children, shey bench district, southwest Ethiopia, 2016.

\begin{tabular}{|c|c|c|c|c|}
\hline \multirow{2}{*}{ Characteristics } & \multicolumn{4}{|c|}{ Stunting } \\
\hline & Yes & No & COR $(95 \% C I)$ & AOR(95\%CI) \\
\hline $\begin{array}{c}\text { Age of children in month } \\
6-11 \\
12-24 \\
>24\end{array}$ & $\begin{array}{c}23(6.5) \\
50(47.6) \\
35(29.6)\end{array}$ & $\begin{array}{l}63(93.5) \\
76(52.4) \\
77(70.4)\end{array}$ & $\begin{array}{c}1 \\
0.55(0.21-0.86) \\
0.80(0.28-0.76)\end{array}$ & $\begin{array}{c}1 \\
0.06(0.02-0.08) * \\
0.12(0.03-0.56) *\end{array}$ \\
\hline $\begin{array}{l}\text { Birth order of index child } \\
\qquad \begin{array}{c}1 \\
2-3 \\
4-5 \\
>5\end{array}\end{array}$ & $\begin{array}{l}37(30.8) \\
31(25.5) \\
27(61.3) \\
13(35.1)\end{array}$ & $\begin{array}{l}83(69.2) \\
92(74.8) \\
17(38.7) \\
24(64.9)\end{array}$ & $\begin{array}{c}1 \\
7.29(2.28-3.86) \\
9.64(2.93-3.78) \\
4.45(1.31-5.17)\end{array}$ & $\begin{array}{c}1 \\
2.01(0.99-2.17) \\
1.61(0.43-1.03) \\
1.05(0.89-2.91)\end{array}$ \\
\hline $\begin{array}{l}\text { Birth interval of index child } \\
\quad>24 \text { months } \\
<24 \text { months }\end{array}$ & $\begin{array}{l}44(41.12) \\
63(29.17)\end{array}$ & $\begin{array}{c}64(58.88) \\
153(70.83)\end{array}$ & $\begin{array}{c}1 \\
1.69(1.03-3.09)\end{array}$ & $\begin{array}{c}1 \\
2.31(1.43-3.08) *\end{array}$ \\
\hline $\begin{array}{c}\text { Educational status of a father } \\
\text { No education } \\
\text { Primary education } \\
\text { Secondary education } \\
\text { Higher institution }\end{array}$ & $\begin{array}{c}15(22.1) \\
57(48.7) \\
28(40 \mathrm{~V} .0) \\
8(11.6)\end{array}$ & $\begin{array}{l}53(77.9) \\
60(51.3) \\
42(60.0) \\
61(88.4)\end{array}$ & $\begin{array}{c}1 \\
0.46(0.18-1.17) \\
0.14(0.61-0.31) \\
0.20(0.82-0.47)\end{array}$ & $\begin{array}{c}1 \\
0.3(0.12-1.21) \\
0.01(0.83-1.45) \\
0.25(0.94-1.01)\end{array}$ \\
\hline $\begin{array}{c}\text { Age of complimentary feeding started } \\
\text { At } 6 \text { months } \\
<6 \text { or }>6 \text { months }\end{array}$ & $\begin{array}{l}36(40) \\
91(37)\end{array}$ & $\begin{array}{c}48(60) \\
149(63)\end{array}$ & $\begin{array}{c}1 \\
1.23(1.01-3.89)\end{array}$ & $\begin{array}{c}1 \\
3.78(1.39-4.25) *\end{array}$ \\
\hline
\end{tabular}

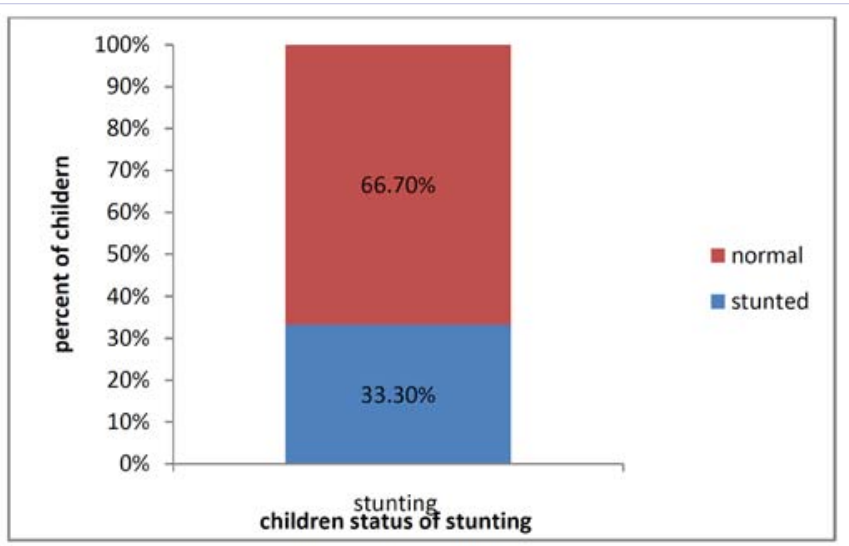

Figure 1: Prevalence of stunting among children 6-59 months age in Shey Bench district, southwest Ethiopia, 2016.

$(33.3 \%)$ as compared with other studies. Children age, age at which complementary feeding started and birth interval were found to be associated factors of stunting. Promoting appropriate maternal feeding at pregnancy including optimal breast feeding, timely starting of complementary feeding and exceeding of birth interval more than 24 months is essential to prevent stunting (chronic malnutrition) among under five children.

\section{Acknowledgement}

We thank Mizan Tepi University for giving technical and some material support to conduct the study. We would also like to thank shey bench district health extension workers and officials for provision of information, facilities and support during data collection. We also acknowledge study participants and their parents for giving the required information.

\section{Ethical consideration}

Ethical approval was obtained from the college of Health sciences, Mizan-Tepi University. Officials of each Facility were also contacted, and permission was granted to conduct the study. Informed written consent was obtained from participants for their participation and the right to withdraw from the study at any time was also communicated to all of them. Undernourished children were referred for to nutritional rehabilitation center according to the national guideline.

\section{References}

1. Monika Blössner , Mercedes De Onis , Annette Prüss-üstün, Diarmid Campbell-lendrum, Carlos Corvalán, Alistair Woodward, et al. World Health Organization Nutrition for Health and Development Protection of the human environment Geneva, 2005.

2. Black Re, Morisss, Baryce J. Where and why are 10 million children dying every year? Lancet. 2003;361(9376):2226-2234.

3. UNICEF, The state of world's children: Children in an Urban. New York: World United Nations Children's Fund, 2012.

4. Scaling up Nutrition a Framework for Action, the Lancet, and "Maternal and Child Under nutrition," 2008; Special Series 2-10.

5. Black Re, Allen LH, Bhutta ZA CaulifiedLE, DeonisM, EzzatiM, et al. Maternal and child under nutrition; global and regional exposures and health consequences. Lancet. 2008;371(9608):243-260. doi: 10.1016/S0140-6736(07)61690-0

6. UNICEF Children and the Millennium Development Goals. Progress for children a report card on nutrition. 2007. 
7. Ministry of Health (MOH) [Ethiopia].The Health Sector Strategic Plan (HSDP-3). MOH, Addis Ababa, Ethiopia. 2005.

8. Addis Continental Institute of Public Health Community-Based SubComponent of Ethiopian National Nutrition Program Baseline Survey Report. 2009. DOI: 10.4236/oalib. 1100425

9. Central Statistical Agency [Ethiopia] and ICF International. 2012 Ethiopia Demographic and Health Survey 2011. Addis Ababa, Ethiopia and Calverton, Maryland, USA: Central Statistical Agency and ICF International.

10. Alive \& Thrive. IYCF Practices, Beliefs, and Influences in SNNPR Region, Ethiopia. 2010;2-10.

11. Alive \& Thrive. IYCF Practices, Beliefs, and Influences in Tigray Region, Ethiopia. 2010.

12. Gobotswang K. Factors associated with nutritional status of the under five children. Amita Pradhana. Asian journal of medical sciences. 2010;1(1):6-8. DOI: 10.3126/ajms.v1i1.2927

13. Mancharia CW, KOG-MAKAU W, Murok NM. Dietary intake, feeding and care practices at children in kathonzweni, Division, Makuenl district, Kenya. East Africa Medical journal. 2004;81(8):402-407.

14.Francesco Branca and colleagues. Nutrition and health in women children, and adolescent girls. BMJ. 2015; 351:h4173. doi: doi. org/10.1136/bmj.h4173

15.Ermias Ayalew. The prevalence of stunting and associated factors among children age 6-59 months at Mizan Aman town, Bench Maji zone, SSNR, ETHIOPIA, 2015

16. Beminet M, Amsalu F, Solomon M, Feleke D. Magnitude of stunting and associated Factors among 6-59 Months Old Children in Hossana Town, Southern Ethiopia. J Clinic Res Bioeth. 2015;6:207. doi:10.4172/21559627.1000207

17.Israt Rayhan, M Sekhander Hayat khan. Factors causing malnutrition in under five children in Bangladesh, journal of nutrition. 2006;5(6):558562.
18. Solomon Demissie, Amare Worku. Magnitude and factors associated with malnutrition in children 6-59 months of age in pastoral community of Dollo Ado district, Somali region, Ethiopia. Science Journal of Public Health. 2013;1(4):175-183. doi: 10.11648/j. sjph.20130104.12

19. Kebede Mengistu, Kassahun Alemu and Bikes Destaw. Prevalence of Malnutrition and Associated Factors Among Children Aged 6-59 Months at Hidabu Abote District, North Shewa, Oromia Regional State. J Nutr Disorders Ther. doi:10.4172/2161-0509.T1-001

20. Birara M, Amsalu F, Bikes D. Prevalence and Factors Associated with Stunting, Underweight and Wasting: A Community Based Cross Sectional Study among Children Age 6-59 Months at Lalibela Town, Northern Ethiopia. J Nutr Disorders Ther. 2014;4:147. doi:10.4172/2161-0509.1000147

21. Hien NN, Kam S. Nutritional status and the characteristics related to malnutrition in children under five years of age in Nghean, Vietnam. J Prev Med Public Health. 2008;41(4):232-240. doi: 10.3961/ jpmph.2008.41.4.232

22. Mandefro A, Mekitie W, Mohammed T, Lamessa D. Prevalence of undernutrition and associated factors among children aged between six to fifty nine months in Bule Hora district, South Ethiopia. BMC Public Health. 2015;15:41. DOI: 10.1186/s12889-015-1370-9

23. Teshale F, Sahilu A, Lamessa D. Factors associated with stunting among children of age 24 to 59 months in Meskan district, Gurage Zone, South Ethiopia: a case-control study. BMC Public Health. 2014;14:800. DOI: 10.1186/1471-2458-14-800

24. Tadiwos Zewdie and Degnet Abebaw. Determinants of Child Malnutrition: Empirical Evidence from Kombolcha District of Eastern Hararghe Zone, Ethiopia. In Quarterly, Journal of International Agriculture. 2013;52(4):357-372. 